\title{
The Moderating Effect of Working Capital Management on the Relationship between Working Capital Determinants and Firm Performance
}

\author{
Ahmad Rizal Mazlan ${ }^{* 1}$ and Choong Yuen Leng ${ }^{2}$ \\ 1 School of Economics, Finance and Banking, Universiti Utara Malaysia \\ 2 Othman Yeop Abdullah Graduate School of Business, Universiti Utara Malaysia
}

\begin{abstract}
This research examines working capital management moderating role on the relationship between the key determinants of working capital and firm performance among 282 public-listed manufacturing firms in Malaysia for the period of 2010 to 2014. In this study, working capital management components are categorized into working capital requirement and net liquid balance. The evidence suggests that the relationship between critical determinants of working capital and firm performance is moderated by both working capital requirement and net liquid balance. Further, the results show that the research framework does form a contemporary working capital management model.
\end{abstract}

Keywords: Working Capital Management, Working Capital Requirement, Net Liquid Balance, Moderation

JEL Classification: G31, O16, L25

Paper Type: Research

\section{INTRODUCTION}

Good working capital management is important because it can positively influence firm performance and therefore it becomes a priority for corporation's management and the board of directors (Ding, Guariglia \& Knight, 2013; Kieschnick, LaPlante \& Moussawi, 2013; Banos-Caballero, Garcia \& Martinez, 2014). The empirical evidence by numerous studies (Lamberson, 1995; Deloof, 2003; Howorth \& Westhead, 2003; Afza \& Nazir, 2007; Garcia \& Martinez, 2007; Arnold, 2008) have shown that quantifying working capital of a business is somewhat difficult due to the differences in business models and also varying risk levels in different economic conditions. In practice, working capital differs across firms

*Corresponding author: E-mail: arizal@uum.edu.my 
by the nature and size of the business, production level, operating cycle, credit policy of the business and other factors (Mandal, Mahavidyalaya \& Goswami 2010). Critically, any decision making made on working capital will have a direct impact on the trade-off between firm profitability and risk (Ranjith, 2008; Madhou, 2011; Abbadi \& Abbadi, 2013).

There is quite a number of literature (Moussawi, LaPlante, Kieschnick, \& Baranchuk, 2006; Padachi, 2006; Noreen, Khan \& Abbas, 2009) which show that working capital management problems exist in many firms. However, according to Sen, Kosal, and Oruc (2009), Paul et al. (2012), Yusuf and Idowu (2012) and Pushpakumar and Yadhav (2014), there is still lack of understanding of working capital management function as a firm effective life-blood and nerve centre. In addition, based on a report (PriceWaterhouseCoopers, 2013), it was shown that the trends of working capital levels had deteriorated year to year by almost $2 \%$ globally with American and Asian companies as the worst performers. However, the report highlighted that the highest working capital improvement opportunity is recorded by manufacturing companies which is estimated to be more than $€ 250$ billion. This indicates that working capital management is a crucial component in manufacturing firms and may significantly influence their financial performance and growth.

Several studies on working capital management (Chiou, Cheng \& Wu 2006; Appuhami, 2008; Hill, Kelly, \& Highfield, 2010) have classified net working capital into a working capital requirement (WCR) and net liquid balance (NLB) instead of a more traditional definition of current assets minus current liabilities. A study by Wasiuzzaman and Arumugam (2013) shows that firm-specific factors such as cash flow, leverage, sales growth, age, and firm size have a significant influence on the investment of operating working capital. Lou and Homburg (2008), Faden (2013) and Lindow (2013) utilized the configurational theory in their studies to examine the determinants of working capital management. Although there are many studies on the determinants of working capital management in Malaysia, none of them looked at the contemporary working capital management model in explaining the current working capital management practices in the manufacturing industry in Malaysia. Therefore, this study fills in the gap by examining the working capital management moderation roles on the relationship between the key determinants of working capital and firm performance, by focusing on the net working capital that has been classified as WCR and NLB.

The objective of this study is to propose a contemporary working capital management model in order to support corporate decision makers to adopt working capital management in a strategic, holistic and sustainable perspective. This can be realized by providing a working capital management model in explaining the current working capital management practices in the industry. The model adopts a configurational theory and Fisher separation theorem as the underlying theories in supporting the working capital management research. The theoretical framework of the study is discussed in the next section.

The remainder of this paper is arranged as follows. Section 2 examines the related literature and highlights the hypotheses of moderation roles between the key determinants of working capital and firm performance. Section 3 explains the research design and model specification, while section 4 discusses the findings of the study. Finally, section 5 provides the conclusion of the study.

\section{LITERATURE REVIEW}

\subsection{Working Capital Requirement and Net Liquid Balance}

Shulman and Cox (1985) pioneered the approach of using working capital requirement (WCR) and net liquid balance (NLB) as an alternative measure of the financial position of 
a firm. It was also used by Hawawini, Viallet, and Vora (1986) who suggested that it is an accounting measure that reveals the amount of capital invested by a firm in its operating cycle. According to Faden (2013), if the working capital requirement is positive, the excess must be financed by either free cash flow or debt; and when it is negative, a firm's operating cycle becomes the permanent source of firm financing. The positive working capital requirement policy is related to the conservative approach to the working capital requirement, and the negative working capital requirement policy is related to the aggressive approach to WCR. It is an effective measure of firm liquidity by highlighting the timing of the firm operating cash inflows and outflows (Rehn, 2012). Meanwhile, NLB consists of the difference between a firm's cash plus marketable security and short-term debts or borrowings, and it is related to firm financial decisions with no direct correlation to firm operations (Faden, 2013). NLB looks at these assets as a primary source of liquidity (Kleiman, 1992) and can predict the financial crisis of a firm (Chiou et al., 2006).

\subsection{Theoretical Framework}

Based on various studies in the field of management (Venkatraman \& Prescott, 1990; Delery \& Doty, 1996; Snow, Miles \& Miles, 2006; and Donaldson, 2006) it was shown that configurational theory derives from the contingency theory which developed by Shortell (1977). The fundamental assumption of the configurational theory is that the concept of fit exists when a firm is aligned with its environment (Lenz, 1980; Gupta \& Govindarajan, 1984; Govindarajan, 1988; Tan \& Litschert, 1994; Langfield-Smith, 1997; Lindow, 2013). The basic model of fit consists of firm characteristics, contingencies, and firm performance. The firm characteristics in this study refer to the firm's working capital management. The optimal level of these firm characteristics changes with the contingencies (Donaldson, 1996). The contingencies include internal and external environments. However, in this study, the contingencies include only the firm's internal environment which is firm-specific. The factors are cash flow, leverage, sales growth, size, and age, and are postulated to be the key determinants of working capital.

Naturally, net working capital can be segregated into two parts, the operational working capital, and the financing of working capital. The operational working capital is an effective measure of firm liquidity using WCR, while the financing of working capital reveals the source of liquidity as measured by NLB.

By adopting a configurational theory approach to working capital management research, it is postulated that in order for a firm to maximize its firm performance, working capital management must be aligned to key determinants of working capital in order to achieve a strategic fit. Once these requirements are achieved, and the strategic fit is achieved, the overall firm performance will naturally be maximized as predicted by the configurational theory (Faden, 2013). Figure 1 shows the layout of a model that simultaneously takes into account the relationship between the key determinants of working capital and firm performance, moderated by working capital management (WCR).

Separately, based on the Fisher separation theorem the net working capital of a firm is segregated into two parts; operational working capital and the working financial capital (Rehn, 2012). The operational working capital is an effective measure of firm liquidity using WCR, while the financing of working capital reveals the source of liquidity measure by NLB. Both of them are recognized and optimized into a consolidated approach to equal to the requirements of the key determinants of working capital of a firm (Shulman \& Cox, 1985). Once these sub-systems requirements are achieved and in equilibrium, the overall organizational performance will naturally be maximized as predicted by the configurational theory (Faden, 2013). 


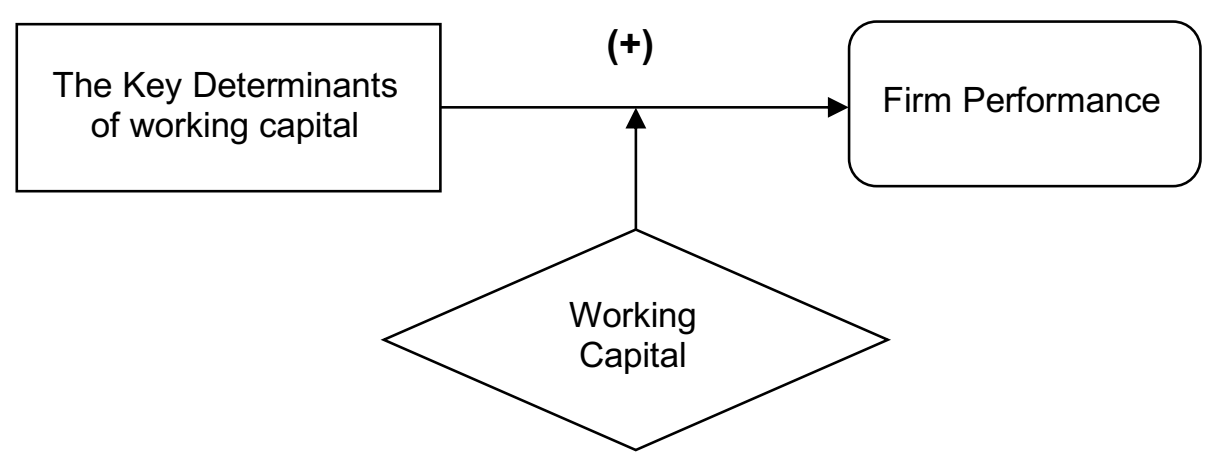

Figure 1. Configurational Theory Adopted in Working Capital Management Study

\subsection{Dependent and Independent Variables}

The dependent variable of this study, firm performance, is proxied by return on assets (ROA) as it is used in many studies to measure how efficiently and effectively a firm manages its operation and uses its assets to generate profits (Raheman, 2012; Mohamad \& Mohd Saad, 2010; Mansoori \& Muhammad, 2012). The independent variables selected for this study are cash flow, leverage, sales growth, size, and age. The cash flow from operations is an indicator used to test the quality of firm profits (Kremer, Rizzuto \& Case, 2000) and signals the competency to create internal resources (Banos-Caballero, GarciaTeruel, \& Martinez-Solano, 2010). It has been shown that firm's capital structure can have an impact on its value or profitability (Modigliani \& Miller, 1963; Myers \& Majluf, 1984 and Rajan \& Zingales, 1995) and several working capital management researchers have included leverage ratio as one of the determinants of firm performance (Padachi, 2006; Abor \& Biekpe, 2009; Mansoori \& Muhammad, 2012; and Saarani \& Shahadan, 2012).

Theoretically, high growth firms tend to receive higher valuation, as they are expected to have better future performance (Klapper \& Love, 2004) but they need to increase their cash holdings and short-term investment (Wasiuzzaman \& Arumugam, 2013). In this study, sales growth is measured by dividing the incremental sales growth (current year sales minus previous year sales) with the previous year's sales (Mansoori \& Muhammad, 2012).

According to Serrasqueiro and Nunes (2008), it is commonly accepted by the researchers in the fields of finance and accounting, industrial economics and strategic management that firm size is considered to be a fundamental variable in explaining company profitability. The size of the firm is measured by the natural logarithm of total assets (Titman \& Wessels, 1998; Jairo, 2008; Mansoori \& Muhammad, 2012; Saarani \& Shahadan, 2012; Wasiuzzaman \& Arumugam, 2013). A firm age shows the number of years a firm has been in existence and operating on a going concern basis. According to previous researchers (Bertrand \& Mullainathan, 2003; Loderer \& Waelchli, 2010), firm age is a determinant of company profitability. Working capital requirement measurement is based on Ding et al. (2013) and Chiou et al., (2006).

According to Sekaran and Bougie (2010), the presence of a moderator may change the initial relationship between the dependent and independent variables. Baron and Kenny (1986) further clarified that the moderator roles either modify the strength and the direction of the relationship between dependent and independent variables. So far, the effects of working capital management acting as a moderator on the relationship between the key determinants of working capital and firm performance in a single model among the manufacturing companies in Malaysia is still yet to be tested. 
Therefore, the following hypotheses are developed for this study:

Hypothesis 1: The relationship between key determinants of working capital and firm performance is moderated by working capital requirement.

Hypothesis 2: The relationship between key determinants of working capital and firm performance is moderated by net liquid balance.

\section{RESEARCH DESIGN AND MODEL SPECIFICATION}

The final sample of the study consists of 282 manufacturing companies out of the total 457 companies classified under manufacturing companies from 2010 to 2014 . Figure 2 shows the research framework of the study. The dependent variable is firm performance measured by return on assets (ROA). The independent variables consisted of the key determinants of working capital selected based on previous studies - cash flow, leverage, sales growth, size, and age.

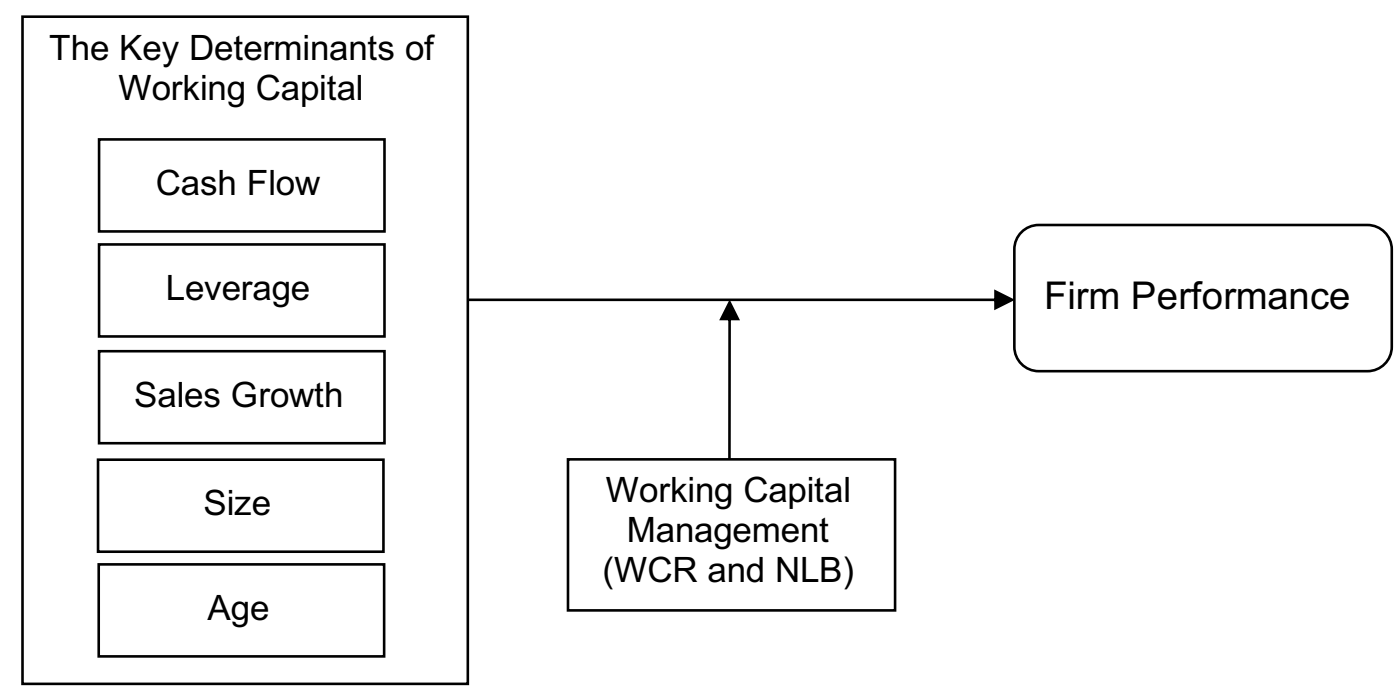

Figure 2. Research Framework

Table 1 summarizes the measurement of the variables supported by the previous studies which have used them.

Table 1. Measurement and operationalization of variables

\begin{tabular}{lll}
\hline Variable & Proxy & Literature \\
\hline Firm & ROA = EBIT/Total Assets & Mohamad \& Mohd Saad (2010); \\
Performance & & Mansoori \& Muhammad (2012); \\
& & Raheman (2012); Palombini \& \\
& & Nakamura (2012) \\
\hline Cash Flow & Operating Cash Flow/Total Assets & Palombini \& Nakamura (2012) \\
\hline Leverage & Total Debt/Equity & Titman \& Wessels (1998); Abor \& \\
& & Biekpe (2009); Mansoori \& Muhammad \\
& & (2012); Saarani \& Shahadan (2012) \\
\hline Sales Growth & Investment/Total Assets & $\begin{array}{l}\text { Abor \& Biekpe (2009): Saarani \& } \\
\text { Shahadan (2012) }\end{array}$ \\
\hline
\end{tabular}




\begin{tabular}{lll}
\hline Variable & Proxy & Literature \\
\hline Size & Log Assets & $\begin{array}{l}\text { Titman \& Wessels (1998); Jairo } \\
\text { (2008);Mansoori \& Muhammad (2012); } \\
\text { Saarani \& Shahadan } \\
\text { (2012);Wasiuzzaman \& Arumugam } \\
(2013)\end{array}$ \\
\hline Age & & $\begin{array}{l}\text { Abor \& Biekpe (2009); Saarani \& } \\
\text { Shahadan (2012) }\end{array}$ \\
\hline WCR & From the date of incorporation until 2014 & Ding, Guariglia \& Knight (2013) \\
& $\begin{array}{ll}\text { \{[(inventories-accounts payable)/cost of } \\
\text { goods sold] + (accounts } \\
\text { receivable/sales)\}/365 }\end{array}$ & Chiou, Cheng \& Wu (2006) \\
\hline NLB & $\begin{array}{l}\text { [(Cash \& cash equivalent + short term } \\
\text { investment) - (short term debt } \\
+ \text { commercial paper payable + long term } \\
\text { debt in a year term)]/total assets }\end{array}$ & \\
& &
\end{tabular}

\section{FINDINGS}

\subsection{Descriptive statistics}

Table 2 displays the descriptive statistics of all the variables in the study. The highest standard deviation of the mean is recorded by leverage (14.89), and the lowest standard deviation of the mean is recorded by WCR $(0.144)$, followed by NLB $(0.202)$, showing that on average, the working capital level of all the companies in the sample does not vary significantly with each other. Most of the skewness and kurtosis values are within the \pm 2 range, indicating that overall, the data is considered to be normally distributed.

Table 2. Descriptive Statistics

\begin{tabular}{|c|c|c|c|c|c|c|c|c|c|}
\hline Measure & Status & ROA & CF & LV & SG & $\mathbf{S}$ & A & WCR & NLB \\
\hline $\mathrm{N}$ & $\begin{array}{l}\text { Valid } \\
\text { Missing }\end{array}$ & $\begin{array}{r}256 \\
26\end{array}$ & $\begin{array}{r}241 \\
41\end{array}$ & 282 & $\begin{array}{r}214 \\
68\end{array}$ & 282 & 282 & 282 & 282 \\
\hline Mean & & 0.905 & 0.826 & 18.510 & 0.905 & 2.416 & 1.272 & 0.258 & 0.000 \\
\hline Median & & 0.962 & 0.909 & 17.008 & 0.962 & 2.362 & 1.255 & 0.247 & -0.019 \\
\hline Std. Devia & & 0.353 & 0.431 & 14.889 & 0.482 & 0.544 & 0.284 & 0.144 & 0.202 \\
\hline Skewness & & -1.280 & -1.192 & 0.500 & -0.954 & 0.802 & -0.157 & 0.471 & 0.285 \\
\hline Std. Error & Skewness & 0.152 & 0.157 & 0.145 & 0.166 & 0.145 & 0.145 & 0.145 & 0.145 \\
\hline Kurtosis & & 3.836 & 1.837 & -0.669 & 4.552 & 1.177 & 0.102 & 0.262 & -0.320 \\
\hline Std. Error & Kurtosis & 0.303 & 0.312 & 0.289 & 0.331 & 0.289 & 0.289 & 0.289 & 0.289 \\
\hline Minimum & & -1.056 & -0.854 & 0.000 & -1.585 & 1.322 & 0.301 & -0.020 & -0.440 \\
\hline Maximum & & 1.841 & 1.734 & 56.256 & 2.401 & 4.540 & 2.013 & 0.828 & 0.600 \\
\hline
\end{tabular}

\subsection{Multivariate Analysis}

Tables 3 and Table 4 show the results of the ordinary least squares (OLS) regression. Following Baron and Kenny (1986) and Frazier, Tix, and Barron (2004) the variables in the research framework are regressed in several stages. Firstly, the dependent variable (firm performance) is regressed against the independent variables, and it is named Model 1. Next, WCR and NLB (moderator) are regressed separately against firm performance, and it is identified as Model 2. In the final stage, the standardized independent variables are multiplied by the standardized WCR and NLB to form interaction variables. Subsequently, they are regressed against firm performance, and it is called Model 3. 
Table 3 shows the results of all the three regression models where WCR is hypothesized to be the moderating variable.

Table 3. Regression results where WCR is hypothesized to be a moderator

\begin{tabular}{|c|c|c|c|c|c|c|}
\hline Variable & $\begin{array}{c}\text { Model } \\
\text { All Predic }\end{array}$ & & $\begin{array}{c}\text { Model } 2 \\
\text { Moderator }\end{array}$ & & $\begin{array}{c}\text { Model } 3 \\
\text { Interaction }\end{array}$ & \\
\hline Cash flow & 0.001 & ** & 0.000 & ** & 0.000 & ** \\
\hline Leverage & 0.364 & & 0.386 & & 0.361 & \\
\hline Sales growth & 0.833 & & 0.684 & & 0.868 & \\
\hline Size & 0.126 & & 0.083 & & 0.046 & * \\
\hline Age & 0.013 & * & 0.025 & * & 0.017 & * \\
\hline F value & 5.590 & & 5.177 & & 3.672 & \\
\hline F change & 5.590 & & 2.826 & & 1.739 & \\
\hline F significant & 0.000 & & 0.000 & & 0.000 & \\
\hline Significant $\mathrm{F}$ change & 0.000 & & 0.094 & & 0.128 & \\
\hline $\mathrm{R}$ square & 0.134 & & 0.147 & & 0.188 & \\
\hline Adjusted $\mathrm{R}$ square & 0.110 & & 0.119 & & 0.136 & \\
\hline $\mathrm{R}$ square change & 0.134 & & 0.013 & & 0.040 & \\
\hline
\end{tabular}

** Regression is significant at 0.01 level (2-tailed)

${ }^{*}$ Regression is significant at 0.05 level (2-tailed)

In model 1, all the independent variables are regressed against firm performance. The $\mathrm{R}$ square value indicates that on average, $13.4 \%$ of the variation in firm performance could be predicted from the variation of cash flow, leverage, sales growth, size, and age, simultaneously. Out of the five predictor variables, the cash flow variable is significant at $p<0.01$, while the firm age is significant at $p<0.05$.

In model 2, the working capital requirement is introduced into the regression model, and the $\mathrm{R}$ square change increased by $1.3 \%$. The $\mathrm{p}$-value related to the $\mathrm{F}$ significant value is 0.000 , and the model is justified to be significant at the $99 \%$ level of confidence. It is observed that the cash flow variable is significant at $p<0.01$, while the firm age is significant at $\mathrm{p}<0.05$.

In model 3, all of the 'standardized' key determinants of working capital (independent variables) are multiplied with the 'standardized' WCR (moderator) to form interaction variables. These interaction variables are then introduced into the model, and the $R$ square change increased by $4 \%$, with an F-change value of 1.739 and $p$-value of 0.000 . The model is justified to be significant at the $99 \%$ level of confidence. Also, it is observed that cash flow variable is significant at $p<0.01$, while firm age and firm size are significant at $p<0.05$ respectively.

The evidence suggests that the relationship between key determinants of working capital and firm performance is moderated by working capital requirement. Therefore hypothesis one is supported.

Table 4 shows the results of all the three regression models where NLB is hypothesized to be the moderating variable. The results for model 1 are similar to that in Table 3 earlier. In model 2, NLB variable is introduced into the model. This has resulted in $\mathrm{R}$ square change to increase by $0.4 \%$. The $\mathrm{p}$-value related to the $\mathrm{F}$ significant value is 0.000 , so the model is justified to be significant at the $99 \%$ level of confidence. In addition, the cash flow variable is significant at $p<0.01$, while the firm age is significant at $p<0.05$. In model 3, all of the 'standardized' key determinants of working are multiplied by the 'standardized' NLB to form interaction variables and are introduced into the model. The R square change increased by $6.8 \%$, with an F-change value of 2.984 and a p-value of 0.000 ; indicating that the model is significant at $99 \%$ level of confidence. In addition, it is observed that cash flow variable is significant at $p<0.01$, while firm age and firm size are significant at $p<0.05$. 
Mazlan, A. R., \& Leng, C. Y.

Table 4. Regression results where NLB is hypothesized to be a moderator

\begin{tabular}{|c|c|c|c|c|c|c|}
\hline Variable & $\begin{array}{c}\text { Model } \\
\text { All Predic }\end{array}$ & & $\begin{array}{c}\text { Model } 2 \\
\text { Moderator }\end{array}$ & & $\begin{array}{c}\text { Model } 3 \\
\text { Interaction }\end{array}$ & \\
\hline Cash flow & 0.001 & ** & 0.000 & ** & 0.000 & ** \\
\hline Leverage & 0.364 & & 0.189 & & 0.185 & \\
\hline Sales growth & 0.833 & & 0.795 & & 0.444 & \\
\hline Size & 0.126 & & 0.118 & & 0.118 & \\
\hline Age & 0.013 & * & 0.012 & * & 0.016 & * \\
\hline F value & 5.590 & & 4.808 & & 4.124 & \\
\hline F change & 5.590 & & 0.912 & & 2.984 & \\
\hline F significant & 0.000 & & 0.000 & & 0.000 & \\
\hline Significant $\mathrm{F}$ change & 0.000 & & 0.341 & & 0.013 & \\
\hline R square & 0.134 & & 0.138 & & 0.206 & \\
\hline Adjusted R square & 0.110 & & 0.109 & & 0.156 & \\
\hline $\mathrm{R}$ square change & 0.134 & & 0.004 & & 0.068 & \\
\hline
\end{tabular}

** Regression is significant at 0.01 level (2-tailed)

${ }^{*}$ Regression is significant at 0.05 level (2-tailed)

Considering the above outcomes, it can be concluded that the relationship between the key determinants of WC and firm performance is moderated by net liquid balance. As a result hypothesis two is supported.

\section{CONCLUSION}

This study extends the existing literature on working capital management by using the WCR and NLB approach to measure net working capital among the public-listed manufacturing companies in Malaysia. Furthermore, it also proposes that configurational theory can be applied whereby strategic fit is achieved when firm characteristics (working capital management) are aligned with the contingencies (key determinants of working capital) in maximizing financial performance. This research contributes to the current literature by identifying the role of working capital management as a moderating variable on the relationship between key determinants of working capital and firm performance.

In this study, the contingencies included only the firm internal environment which covers only firm-specific factors or variables. Future research may want to include external factors such as macroeconomic variables such as the GDP and the inflation rate which play an important role in firms' investment allocation in trade credit and inventories (Smith, 1987; Walker, 1991).

\section{REFERENCES}

Abbadi, S. M. \& Abbadi, R. T. (2013). The determinants of working capital requirements in Palestinian industrial corporations. International Journal of Economics and Finance, 5(1), 6372.

Abor, J. \& Biekpe, N. (2009). How do we explain the capital structure of SMEs in sub-Saharan Africa? Evidence from Ghana, Journal of Economic Studies, 36(1), 83-97.

Afza, T. \& Nazir, M. S. (2007). Is it better to be aggressive or conservative in managing working capital? Journal of Quality and Technology Management, 3(3), 11-21.

Appuhami, R. (2008). The impact of firms' capital expenditure on working capital management: An empirical study across industries in Thailand. International Management Review, 4, 11-24.

Arnold, G. (2008). Corporate Financial Management. (4th ed.). Essex: Prentice Hall.

Banos-Caballero, S., Garcia-Teruel, P. J., \& Martinez-Solano, P. (2014). Working capital management, corporate performance, and financial constraints. Journal of Business Research, 67, 332-338. 
Baron, R. M., \& Kenny, D. A. (1986). The moderator-mediator variable distinction in social psychological research: Conceptual, strategic, and statistical considerations. Journal of Personality and Social Psychology, 51(6), 1173-1182.

Bertrand, M., \& Mullainathan, S., (2003). Enjoying the quiet life? Corporate governance and managerial preferences. Journal of Political Economy. 111(5), 1075.

Chiou, J. R., L. Cheng L., \& Wu H. W. (2006). The determinants of working capital management. Journal of American Academy of Business, 10, 149-155.

Deloof, M. (2003). Does working capital management affect the profitability of Belgian firms? Journal of Business Finance and Accounting, 30(3/4), 573-588.

Delery, J., \& Doty, D. (1996). Modes of theorizing in strategic human resource management: Tests of universalistic, contingency, and configurational performance predictions. Academy of Management Journal, 39(4), 802-835.

Ding, S., Guariglia, A. \& Knight, J. (2013). Investment and financing constraints in China: does working capital management make a difference? Journal of Banking \& Finance, 37, 14901507.

Donaldson, L. (1987). Strategy and structural adjustment to regain fit and performance: In defense of contingency theory. Journal of Management Studies, 24(1), 1-24.

Donaldson, L. (1996). The normal science of structural contingency theory. Handbook of organization studies. London: Sage.

Donaldson, L. (2006). The contingency theory of organizational design: Challenges and opportunities. New York: Springer.

Faden, C. (2013). Optimizing firm performance. Alignment of operational success drivers on the basis of empirical data. Wiesbaden: Springer Gabler.

Frazier, P. A., Tix, A. P., \& Barron, K. E. (2004). Testing moderator and mediator effects in counselling psychology research. Journal of Counselling Psychology, 51(1), 115.

García-Teruel, P. J., \& Martínez-Solano, P. (2007). Effects of working capital management on SME profitability. International Journal of Managerial Finance, 3(2), 164-177.

Govindarajan, V. (1988). A contingency approach to a strategy implementation at the business-unit level: Integrating an administrative mechanism with strategy. Academy of Management Journal, 31(4), 838-853.

Gupta, A. K. \& Govindarajan, V. (1984). Business unit strategy, managerial characteristics and business unit effectiveness at strategy implementation. Academy of Management Journal, 17(1), 25-41.

Hawawini, Viallet, \& Vora, (1986). Industry influence on corporation working capital decisions. Sloan Management Review, 27, 15-24.

Hill, M., Kelly, G.W., \& Highfield, M. (2010). Net operating working capital behaviour: A first look. Financial Management, 39(12), 783-805.

Howorth, C. \& Westhead, (2003). The focus of working capital management in UK small firms. Management Accounting Research, 14, 94-111.

Jairo, I. (2008). The use of structural equation modelling (SEM) in capital structure empirical analysis. KCA Journal of Business Management, 1 (1), 11-35.

Kieschnick, R., LaPlante, M., \& Moussawi, R. (2013). Working capital management and shareholders wealth. Review of Finance, 17, 1827-1852.

Klapper, L. F. \& Love, I., (2004). Corporate governance, investor protection, and performance in emerging markets. Journal of Corporate Finance, 10(5), 703-728.

Kleiman R. T. (1992). Liquidity measures. New developments alleviate old deficiencies. Business Credit, 94 (9), 4.

Kremer, C., Rizzuto, R. \& Case, J. (2000). Managing by the numbers. A commonsense guide to understanding and using your company's financials. Cambridge, Massachusetts: Perseus Publishing.

Langfield-Smith, K. (1997). Management control systems and strategy: A critical review. Accounting, Organization and Society, 22(2), 207-232.

Lamberson, M. (1995). Changes in working capital of small firms in relation to changes in economic activity. Mid-American Journal of Business, 10(2), 45-50.

Lenz, R. T. (1980). Environmental strategy, organization structure, and performance: Pattern in one industry. Strategic Management Journal, 1(3), 209-222. 
Lindow, C. M. (2013). A strategic fit perspective on firm performance. Leipzig, Germany: Springer Gabler.

Loderer, C., \& Waelchli, U., (2010). Firm age and performance. Unpublished manuscript, MPRA Paper 26450, University Library of Munich, Germany.

Lou, X. \& Homburg C. (2008). Satisfaction, complaint, and the stock value gap. Journal of Marketing, 72(4), 29-43.

Madhou, A. K. (2011). Development of a risk-adjusted working capital model: Empirical evidence on its contribution to profitability and credit ratings. Unpublished Ph.D., RMIT University, Australia.

Mandal, N., Mahavidyalaya B.N.D.S. \& Goswami B. S. (2010). Impact of working capital management on liquidity, profitability and non-insurable risk and uncertainty-bearing: A case study of oil and natural gas commission (ONGC). Great Lake Herald, 4(2).

Mansoori, E. \& Muhammad, J. (2012). Determinants of working capital management: Case of Singapore firms. Research Journal of Finance and Accounting, 3(11). 15-23.

Modigliani F. \& Miller M.H. (1963). Corporate income taxes and the cost of capital: A correction. American Economic Review, 53.433-443.

Mohamad, N. E. A. B., \& Mohd Saad, N. B. (2010). Working capital management: The effect of market valuation and profitability in Malaysia. International Journal of Business and Management, 5(11), 140-147.

Moussawi, R., LaPlante, M., Kieschnick, R. \& Baranchuk, N. (2006). Corporate working capital management: Determinants and consequences. Working Paper, Baylor University.

Myers, S. C. \& Majluf, N.S. (1984). Corporate financing and investment decisions when firms have information that investors do not have. Journal of Financial Economics. 13(2), 187-221.

Noreen, U., Khan, S. K. \& Abbas, Q. (2009). International working capital practices in Pakistan. International Research Journal of Finance and Economics, 32, 160-170.

Padachi, K., (2006). Trends in working capital management and its impact on firm's performance: An analysis of Mauritian small manufacturing firms. International Review of Business Research Papers, 2, 45-58.

Palombini, N. V. N. \& Nakamura, W. T. (2012). Key factors in working capital management in the Brazilian market. Rev. Adm. Empres. [online], 52(1), 55-69.

Paul, S. Y., Devi, S. S. \& Teh, C. G. (2012). Impact of late payment on a firm's profitability: Empirical evidence from Malaysia. Pacific-Basin Finance Journal, 20, 777-792.

PriceWaterhouseCoopers (2013). Working Capital: opportunities knock. How companies can tap the cheapest source of cash in the 'new normal.' Retrieved 10 September 2015, from https://www.pwc.com/gx/en/financial-services/publications/assets/pwc-working-capitalfinal.pdf

Pushpakumar, B. \& Yadhav, P. K. (2014). A study on working capital in public enterprises. CAMS Journal of Business Studies and Research. 5, 1-21.

Raheman, A. (2012). Analyzing the working capital management and productivity growth of the manufacturing sector in Pakistan. Unpublished doctoral dissertation. Comsats Institutes of Information Technology Islamabad-Pakistan.

Rajan, R. \& Zingales, L., (1995). What do we know about capital structure? Some evidence from international data. Journal of Finance, 50(5), 1421-1460.

Ranjith, B. A. (2008). The impact of firms' capital expenditure on working capital management: An empirical study across industries in Thailand. International Management View, 4(1), 11-24.

Rehn, E. (2012). Effects of working capital management on company profitability. Unpublished master thesis, Hanken School of Economics, Finland.

Saarani, A. N. \& Shahadan, F. (2012). The determinant factors of working capital requirements for enterprise 50 (E50) firms in Malaysia: Analysis using structural equation modelling. Scottish Journal of Arts, Social Sciences and Scientific Studies, 5 (2).52-66.

Sekaran, U., \& Bougie, R. (2010). Research methods for business (5th ed.). United Kingdom: John Wiley \& Son Ltd.

Sen, M., Kosal, C. D., \& Oruc, E. (2009). Relationship between the efficiency of working capital management and company size. Retrieved October 4, 2013, from http://www.opf.slu.cz/kfi/icfb/proc2009/pdf/33_Sen.pdf. 
Serrasqueiro, Z. S., \& Nunes, P. N. (2008). Performance and size: Empirical evidence from Portuguese SMEs. Small Business Economics, 31(2), 195-217.

Shortell, S. (1977). The role of the environment in a configurational theory of organizations. Human Relations, 30, 275-302.

Shulman, J. M. \& Cox, R. A. K. (1985). An integrative approach to working capital management. Journal of cash management, 5(6), 64-68.

Smith, J. K., (1987). Trade credit and informational asymmetry, Journal of Finance 42, 863-872.

Snow, C. C., Miles, R. E., \& Miles, G. (2006). The configurational approach to organization design: Four recommended initiatives. New York: Springer.

Tan, J. J., \& Litschert, R. J. (1994). Environment strategy relationship and its performance implications: An empirical study of the Chinese electronics industry. Strategic Management Journal, 15, 1-20.

Titman, S., \& Wessels, R. (1988). The determinants of capital structure choice. The Journal of Finance, 43(1), 1-19.

Venkatraman, N., \& Prescott, J. E. (1990). Environment-strategy co alignment: An empirical test of its performance implications. Strategic Management Journal, 11(1), 1-23.

Walker, D., (1991). An empirical analysis on financing the small firm. Advances in Small Business Finance, 47-61.

Walsh, C. (2006). Key management ratios: The clearest guide to the critical numbers that drive your business $\left(4^{\text {th }}\right.$ ed.). Glasgow: Pearson Education Limited.

Wasiuzzaman, S. \& Arumugam, V. C. (2013). Determinants of working capital investment. A study of Malaysian public listed firms. Australasian Accounting Business and Financial Journal, 7(2).63-83.

Yusuf, B. R. \& Idowu, K. A. (2012). An investigation of the effect of aggressive working capital technique on the performance of manufacturing firms in Nigeria. International Research Journal of Finance and Economic, 96, 90-100. 